\title{
The Europeanisation of Romanian football: What do UEFA country coefficients reveal?
}

\author{
Vlad I. ROȘCA \\ The Bucharest University of Economic Studies, Bucharest, Romania \\ vlad.rosca@fabiz.ase.ro
}

\begin{abstract}
After the fall of communist regimes, Central and Eastern European states have been encouraged to Europeanise by aligning to Western standards. Even if politics and economy have been primarily concerned, football has often allowed easier and faster contact to occidental cultures than other facets of the civic society did. From a football club perspective, being Europeanized involves the abilities to establish a constant presence in continental cups, as well as to raise performances to higher, international standards. The game itself has strongly Europeanised over the years, with UEFA transforming its two continental inter-club competitions into iconic brands, 'pluralizing' fan attention between domestic leagues and international cups, with the latter ones enjoying increased awareness. While some UEFA member associations have properly mastered the process of Europeanisation, others saw their teams struggle to perform in Europe, which led to the creation of a cleavage between 'elitist' and 'periphery' countries. Results of Romanian teams in European competitions have fluctuated over the past and a half decade. The purpose of this research is to find out how far Europeanised Romanian football can be currently considered. The research question asks what is the current European dimension of Romanian club football? UEFA Country Coefficients are used as input data for computing statistical observations such as means and standard deviations, which are then compared with a three-levelled center-periphery model designed by Maguire (2001). Results indicate that Romanian football is still far away from the continental 'center' status it pretends to have. The Discussions section addresses some of the reasons for this distance. The article tries to fill in a research gap as most Europeanisation studies so far have focused on the hardcore concepts of economics, politics, or law, but rather few on social and cultural alignments, such as football (Pyta, 2005).
\end{abstract}

Keywords: Europeanisation, Football, internationalization, center-periphery, UEFA, Champions League, UEFA Coefficients

Please cite the article as follows: Roșca, V.I. (2017), "The Europeanisation of Romanian football: What Do UEFA country coefficients reveal?", Management \& Marketing. Challenges for the Knowledge Society, Vol. 12, No. 4, pp.652-673. DOI: 10.1515/mmcks-2017-0038.

\section{Introduction}

2005/2006 saw the best European season for Romanian football after the country escaped Communist rule in December 1989. Used to watching their teams breakdown in the early stages of international competitions, Romanian fans now witnessed a whole unexpected dimension of the domestic football. After winning their respective groups, Steaua and Rapid advanced to the knock-out phases of the UEFA Cup and clinched what collective memory might remember as one of the most exhilarating instants of Romanian post-communist football up to date: a quarter-final between the two clubs of Bucharest (Schulz, 2008). That season's performances (to which another club of Bucharest, Dinamo, contributed as well, and which saw the Steaua and Rapid players be tagged with the alias 'the uefantastics'), destined Romania to finish first in 
the UEFA Country Coefficients Rankings for 2005/2006: a performance never had before and never to be repeated again. Apart from rankings and on-pitch success, what that season's events brought along was a sense of hope: pampered with continental glory, footballers and fans now discovered how it felt like to have a say in Europe. It was one of the seldom moments when Romanian football (and not only, as the feelings were transferred to the wider civic society as well) felt 'Europeanised'.

Studies on 'Europeanisation' have grown into a substantial research topic, most of them focusing on how European economies and politics were shaped in a commonwealth fashion (Gherghina, 2013; Lodge, 2002). Researchers have audited the fundamentals of European integration with highest of attention, gathering around a central rationale of assimilation politics: how domestic governance takes over communitarian leadership, thought and behavior (Pavlovaite, 2003; Sofos, 2009). The introduction of a universal currency and the construction of a joint market have cultivated a school of thought and of research directed towards the analysis of a transcendental, boundaryless establishment of European affiliation, built around three key concepts of integration: politics, economics and law. Yet Pyta $(2015$, p. 1) believes that in heavily focusing on these hardcore concepts, scholars have ignored that a softer side is also needed for Europeanisation to provide socio-cultural meaning. This research paper goes along Pyta's idea of the feeble link in nearly all Europeanisation attempts: collective identity. Football can be one of the social phenomena to create this shared identity. As the effervescence around the 'uefantastics' of 2005/2006 has shown, football can create genuine European narratives and offer a continental dimension at levels unprecedented for those witnessing the game. As Romania suddenly counted in Europe, attention grew at a level that clashes in the national league were unable to reach, and fans started hoping that Romania can break away from its underdog mantra and become a powerful nation in European football.

Unfortunately, future results have not risen to expectations. A decade later, all four teams that have entered European competitions on behalf of Romania were eliminated in the preliminary rounds, which meant no European cup competitions for Romania in that 2015-2016 season at all.

A return to poor international performances can be a menace to the European dimension of an UEFA member country. The purpose of this research is to discover just how Europeanised Romanian football can be considered nowadays (i.e. where it is heading towards), in a context in which increasing attention is awarded to European performances and very often the quality of a club is judged by its continental results. For reaching its purpose, the paper makes use of two concepts briefly presented previously, but upon which the Literature Review will further expand: 'Europeanisation', and the 'center-periphery' model. This preliminary section of the research tries to: make a general presentation of 'Europeanisation' in spite of a lack of consensus in scientific definitions; give accounts on the 'center-periphery' model and how it can be linked to Eurocentrism; show how decisions made by UEFA have Europeanised the game, but also how they might just have widened the partition of center and periphery. These foregoing steps of conceptual clarification try to set the grounds for the Methodology, Analysis and the Discussions sections. The Methodology section presents the Research Question and the Research Hypothesis, as well as what 
sample data is used and how it is collected. Hence, the Methodology also offers a presentation of what the UEFA Country Coefficients are, how they are calculated and what their importance is for European football configurations, as well as for the entire process of Europeanising the game. The Data Analysis section describes the calculations that have been made and the mathematical formulas used, granting particular attention to the computations of means $(\mu)$ and standard deviations $(\sigma)$, around which the statistical feats of this paper are built. Several historical references to the Romanian football of the 1980's and 1990's are, in some cases, used for data interpretations, which are backed up by graphs employed for aiding better understanding of the topics. The Results Discussion section answers the Research Question and the Research Hypothesis. In doing so, it attempts a descent in the conceptual ideas of Europeanisation, returning to and connecting with the pictures created in the Literature Review so as to follow a logical path towards the awaited answers to the main question and hypothesis. The Discussions also argue if Romanian football has managed to subscribe to Habermas' (1990) idea of pluralization for being able to modernize itself, or whether it has been left behind with a slower alignment to the West - which is defined as the horizon to be met by Europeanisation efforts (König, 1992). The article ends with several conclusions, limitations and future research ideas.

\section{Literature review}

Although the number of scientific works about Europeanisation constantly increases, there still exists enough confusion and dispute about how to render the concept (Buller and Gamble, 2002; Börner and Eigmüller, 2015; Denti, 2014; Kaina et all., 2015). What Europeanisation includes for sure is the relationship between a national (e.g. a sovereign state, a government, an economy) and a European entity (e.g. the geographical continent or the European Union) (Cowles et all., 2001; Goetz and Hix, 2001; Ladrech, 1994). Taking the national-continental liaison for granted, one of the hands-down approaches to trace Europeanisation would be to present it as the impact that Europe has got on a country (Carbone and Quartapelle, 2016; Özer, 2016). Most researches tend to focus on the positive impact, looking at Europe as a propeller that drives countries onward (Afonso, 2010). Wessels (2000) believes that Europeanisation can unclose the state from its rudimentary domestic demeanors and open it to the supranational European level. Studies are looking at how systems, mentalities and behaviors are being changed from a national towards an European paradigm, demonstrating that Europeanisation is not a finite goal, but an ongoing nonuniform process (of thinking, of becoming European in the detriment of national) without a clearly defined end (Atikcan, 2010; Economides, 2005; Rees and Connaughton, 2009). Accordingly, Europeanisation can be interpreted as a convergence to Europe (Bürzel, 1999). A particular subset of academic literature that has seen a galloping evolution post 1990, influenced by the reshaping of Central and Eastern Europe (CEE) geopolitics after the disintegration of communist regimes, grants attention to the transformative and reformative power of Europeanisation (Haughton, 2007; Olsen, 2002; Yllmaz, 2016). Building on Wessels' idea that CEE states needed an outward help for running off from out-of-date bureaucratic habits induced by their former regimes, Goetz (2001, p. 1036) identifies a Europeanisation à 
la "Eastern style", concerned with how the new democratic states of the former Eastern Bloc are to get (or to be) aligned Western European practices. The cue in understanding Goetz's point is figuring out to what extent totally different political systems and social behaviors can be aligned to Western mentalities yet new to them during the 1990's. The necessity within resided, in the first and a half decade after the collapse of the Bloc, in modernizing the CEE states and integrating them into the Occidental way of doing things for a purposed enlargement of the European Union (Ilieva and Wilson, 2011). The positive direction of Europeanisation is identifiable here within the goal of the process itself: to help countries ascend to unattained levels, hence to transform domestic realities into European ones (Lippert et all., 2001).

A relevant theory for understanding this quest for alignment and for analyzing international relationships between European nations and the continent is the "center-periphery" theory, which tries to describe the relationship between an evolved 'center' that possesses influence and power, and a rudimentary 'periphery' that has a marginal position in international relationships (Hrebenciuc, 2017a, 2017b; Pisciotta, 2016; Postiglione, 2005; Zgaga, 2014). Champion (2005, p. xiv) looks at the center-periphery cleavage as an Eurocentric model, with poorly developed Eastern and Central European countries shifting attention from their own national perspectives to a larger capacity: the Western civilization, regarded as a savior.

Just as with other sectors or industries, the 'soccerspace' has also become highly Europeanised (Brand et al., 2013; Martin, 2005). Mutz (2015) argues that in a continuously globalizing world, people are not only interested in what happens within their national boundaries, but also keep their eyes on international occurrences. Taking football as an example, the author goes on to claim that there is an increasing attention granted by fans to international state-of-the-art football competitions at the expense of domestic leagues, especially so in countries with feeble national championships.

The magnitude of Europeanisation in football may be explained by the share of interest that European club tournaments have claimed for themselves. There are currently two major yearly competitions played across Europe: the UEFA Champions League, and the UEFA Europa League (Geeraert, 2016; Hughson et al., 2016). The competitions are open to the finest teams from each European member country affiliated with UEFA (Dunmore, 2011, p. 241), with participation rights awarded to the teams best placed in the standings of the regular domestic football leagues at the end of a season, the top seeds advancing to the Champions League and the forthcoming ones to Europa League (Collie, 2003).

The original rules of 1955 saw that each country was allowed to send one team (the winners of the national league) to the European Cup and one team to the InterCities Fairs Cup (Rodríguez et al., 2015). Both competitions were played in a knockout format, with the team winning a two-rounds, home and away match series advancing to the next round, at the expense of the losing team, which was eliminated from the tournament (Flores et al., 2015; Morgan, 2017). As UEFA has built much of its success and prestige on the continental inter-club competitions (Kassimeris, 2007, p. 14), a call for action was needed to make the competitions more attractive and more powerful. Two of the major directions of action concerned the number of teams welcomed to European cups and the number of matches played. When revamping the 
Inter-Cities Fairs Cup to the UEFA Cup in 1971, UEFA allowed the bigger country members to send more than one club, increasing the attractivity of the tournament with stronger head-to-head derbies, even leading to the creation of international rivalries (Olsson, 2011, p. 21). This idea was to prove one of the cornerstones of modern European club football, as starting with 1992 the Champions League followed the same route of gradually increasing the number of participating teams up to 32 , in order to allow stronger matches to be played and to make the competition more attractive for fans and for media alike. In parallel, during the 1990's and 2000's, both tournaments have been redesigned to a round robin format, with group stages being introduced before advancing to eliminatory ties. This saw the number of matches increase and also reduced the risk of big, revenue-driving clubs, to be eliminated prematurely (Siekmann, 2012, p. 217). Adding to this that matches were broadcasted live on TV has created a pan-European market of habitual football consumption (McNamara, 2015, p. 82), subtly sweeping attention away from domestic games, hence building the supranational attention praised by Wessels (2000) at the harm of the national.

Following drastic changes of societal and football landscapes in recent history, UEFA has reconsidered its governance over continental club competitions in a fashion that has eventually allowed more power to elite clubs (Holt, 2007). With the rise in media consumerism and marketing capabilities, there was a need to exploit the commercial potential of football powerhouses (Brand and Niemann, 2006, p. 136). As time went by, the rich seemed to become richer, Menary (2016) demonstrating that prize money distribution for group stage participation in European competitions still benefits the elite clubs and is disproportionate to less significant clubs.

This has led researchers to raise the question of a fractionalization in European football: major clubs entering an elitist virtuous circle that permits them to constantly increase their cash-in abilities and football performances, and less potential clubs trying to keep the pace or even drifting further away (Kesenne, 2007; Lago et al., 2016). Szerovay et al. (2017) describe these latter clubs as belonging to the peripheral countries of football: countries with a rather backward football culture, whose influence in the international game is inferior to the role of core (elitist) countries, or even insignificant at all. International success obtained by periphery countries of football is incidental, an outcome of chance, rather than deliberate preparation.

In the context of increasing attention directed towards the Champions League and Europa League, which are transformed into the new standards of quality, often at the expense of domestic leagues, becoming Europeanised in football can be defined as being able to establish a constant presence in UEFA club competitions and to perform well at continental level. These two latter conditions are of importance for a country hoping to have a say in Europe. With fan and media attention moving away from national to continental level as a result of the internationalization of the game, a football nation can consider itself Europeanised when able to be consistent and keep pace in European competitions so as to move away from a peripheral to a central position in soccer's geopolitics. 


\section{Methodology}

Considering both the changes made by UEFA, as well as the international performances of Romanian football over the past decade, it can be interesting to find out in how far Romanian club football can be considered Europeanised nowadays, judging by the standards raised by the continent's governing body of football.

The research question asks: What is the current European dimension of Romanian club football?

A three-levelled 'center-periphery' scale inspired by Maguire's (2001) categorization of global sports relationships is used to answer the question. Compared to most other researches that used a 'center' and a 'periphery', Maguire considers that it is fair to add a third, 'semi-peripheral' dimension to assert the influence and performances of global sporting nations.

The conceptual model operates with raw data from the UEFA Country Ranking Coefficients. UEFA Coefficients are numerical data used for rating and ranking clubs in the European competitions. Two different coefficients are calculated: one for each club and the other for the entire country. This paper uses the latter one, as it aims to assert Romania's dimension in Europe as a member association of UEFA, not for each of its individual clubs. The country coefficient takes into account the aggregate performances of all participating clubs. UEFA coefficients are calculated as an average by dividing the total number of points that the clubs from a country gather during a European season to the total number of teams from that country that have entered the competition when it began (so, as the number of entering teams is fixed, the more teams are eliminated prematurely from the competition, the lower the coefficient will be, because the points accumulated by the teams still remained in play is not divided to the number of teams left, but to the number of teams that have started) (Morrow, 2003, p. 196).

Official UEFA country coefficient standings indicate that Romania is a rather mid-table-ish football nation. Excepting the out of the ordinary 2005-2006 and 20062007 seasons (when it was the $1^{\text {st }}$, respectively $4^{\text {th }}$ European country in terms of coefficients), Romania never again managed to find its way among the best ten countries on the continent, its places ranging between $12^{\text {th }}$ (twice: 2013, 2014) and even as low as $30^{\text {th }}$ out of 55 . While these results and the European comparisons are rather self-speaking, it would be interesting to see how Romanian football has changed over years compared to its own performances. Therefore, this research doesn't aim to compare Romania's coefficients with other countries' coefficients, but to carry out a longitudinal study of Romania's own coefficients and to analyze what the statistics indicate about the evolution of the domestic clubs in Europe compared to previous performances. Apart from this, another research objective is to identify the European dimension of Romanian club football and to explain why that dimension is being held.

The Research Hypothesis claims that: Romanian club football has a peripheral European dimension. 
The raw data collected for this research consists of Romania's UEFA country coefficients for 13 years (2004-2017), and is displayed in Table 1. Based on these bare numbers, statistical indicators have been calculated in order to find an answer to the research question and to test the research hypothesis.

Table 1. Romania's UEFA Country Coefficients (2004-2017)

\begin{tabular}{|c|c|c|c|}
\hline Season & $\begin{array}{c}\text { UEFA Country } \\
\text { Coefficient }\end{array}$ & Season & $\begin{array}{c}\text { UEFA Country } \\
\text { Coefficient }\end{array}$ \\
\hline $\mathbf{2 0 1 6 - 2 0 1 7}$ & 3.300 & $\mathbf{2 0 0 9 - 2 0 1 0}$ & 6.083 \\
\hline $\mathbf{2 0 1 5 - 2 0 1 6}$ & 2.250 & $\mathbf{2 0 0 8 - 2 0 0 9}$ & 2.642 \\
\hline $\mathbf{2 0 1 4 - 2 0 1 5}$ & 5.125 & $\mathbf{2 0 0 7 - 2 0 0 8}$ & 2.600 \\
\hline $\mathbf{2 0 1 3 - 2 0 1 4}$ & 6.875 & $\mathbf{2 0 0 6 - 2 0 0 7}$ & 11.333 \\
\hline $\mathbf{2 0 1 2 - 2 0 1 3}$ & 6.800 & $\mathbf{2 0 0 5 - 2 0 0 6}$ & 16.833 \\
\hline $\mathbf{2 0 1 1 - 2 0 1 2}$ & 4.333 & $\mathbf{2 0 0 4 - 2 0 0 5}$ & 5.500 \\
\hline $\mathbf{2 0 1 0 - 2 0 1 1}$ & 3.166 & \multicolumn{2}{|l}{} \\
\cline { 1 - 3 } & \multicolumn{2}{|l}{}
\end{tabular}

Source: Kassies (2017).

One of the main reasons why coefficients have been gathered only starting with 2004 onwards is that, prior to that year, the way of calculating the index was slightly different, with UEFA bringing several changes between 1999 and 2003, then setting for the current formula since 2004 (Page and Page, 2008, p. 136). Although the upcoming sections of this paper will make references to results obtained by Romanian football prior to 2004, using them as arguments to demonstrate issues being discussed and to facilitate a better understanding of the findings, the coefficients for the statistical calculations have only been chosen from 2004 onwards so as to avoid any potential distortions.

\section{Data analysis}

A Mean $(\mu)$ and a Standard Deviation $(\sigma)$ of the UEFA coefficients, where $\mathrm{i}=1$ and $\mathrm{N}=$ 13, were first computed:

$$
\mu=\frac{5.500+16.833+11.333+2.600+2.642+6.083+3.166+4.333+6.800+6.875+5.125+2.250+3.300}{13}=\frac{76.840}{13}=5.911
$$

The mean $(\mu)$ of the UEFA Country Coefficient for the thirteen years taken into account indicates a value of 5.911 points per season that the Romanian football clubs have accumulated, in the conditions of a minimum value equal to 2.250 and a maximum value 16.833 . Compared to $\mathrm{min} / \mathrm{max}$, the $\mu$ value shows that the continental performances of the domestic teams were closer to the lower end than to the maximum.

The Standard Deviation $(\sigma)$ is 4.11 and has been calculated according to the following formula:

$$
\sigma=\sqrt{\frac{1}{N} \sum_{i=1}^{N}\left(\chi_{i}-\mu\right)^{2}}=\sqrt{\frac{1}{N} \sum_{i=1}^{13}\left(\chi_{1}-\mu\right)^{2}+\cdots+\left(\chi_{13}-\mu\right)^{2}}=4.114
$$


where:

- $\mathrm{N}$ is the set of cardinal numbers for the competitional seasons taken into account in this research $(=13)$;

- $\chi_{i}$ represents the individual values of every UEFA country coefficient for each of the thirteen seasons analyzed, hence a range between $\chi_{1}$ and $\chi_{13}$;

- $\mu$ represents the mean value of the country coefficients.

Using the Standard Deviation and adding to/subtracting it from the mean, we find out that it is normal for Romanian football to offer European club performances situated between 1.80 and 10.02, which is a large interval (and also starting from a value very close to zero):

$$
\begin{gathered}
\mu+\sigma=5.911+4.114=10.024 \\
\mu-\sigma=5.911-4.114=1.796
\end{gathered}
$$

The significance of 1.80 can be grasped if thinking that UEFA offers two points per victory. In absolute terms, this is similar to less than one victory on average obtained among the participating Romanian teams. In 2000/2001, Romania had a coefficient of 0.833 . Of the three clubs starting in Europe that season, only Rapid Bucuresti made it past qualifiers, but was immediately eliminated in the first round of the UEFA Cup. The success rate for that season for all three teams was of $13 \%$ wins out of all matches played (one match won, two draws, five defeats). In relative terms, a 1.80 coefficient would mean about two victories and five defeats (success rate 28\%). Assuming there are three teams participating for Romania in European cups, two of them would only play a home-and-away encounter and be eliminated directly after the first preliminary round, while a third team might make it through one more stage, only to be eliminated there. The $(\mu-\sigma)$ value suggests that there is nothing abnormal with such a display of Romanian football in Europe. On the contrary, it can be expected to occur at any time. Also true, though, is that the upper normal value of $(\mu+\sigma)$ can be situated at 10.02, a coefficient level surpassed only twice in thirteen years (2005/2006, 2006/2007), so rather unlikely to occur. Keeping the proportions, a 10.02 coefficient would mean around 24 European victories in a season. The last time something close to this happened was in the season when Steaua played the semifinal of the UEFA Cup (21 victories for the three clubs of Bucharest). What these numbers say is that Romania doesn't really have a consolidated position in European club football: its performances in any given season can vary between being eliminated in the preliminary rounds, and reaching the semi-finals or finals of European Cups although the distribution places the mean value $\mu$ closer to the former, so a fan can rather expect his team to be rapidly eliminated from the competition than to reach the upper stages. In only seven occasions out of thirteen have Romanian teams got past the group stages of European competitions, on four occasions they were then immediately eliminated in the round of 32 , three times they made it to the round of 16 , and only once in the quarterfinals and semifinals (both in 2005/2006).

Figure 1 graphically displays the Mean and the Standard Deviation computations. The average indicates where ordinary European results of Romanian clubs are placed. With the help of the Standard Deviation, we can find out where normal performances should be placed $(\mu+\sigma)$, as well as where the level of 
abnormality is $(\mu-\sigma)$. What is above $(\mu+\sigma)$ or below $(\mu-\sigma)$ is considered to be extraordinary, either positively or negatively.

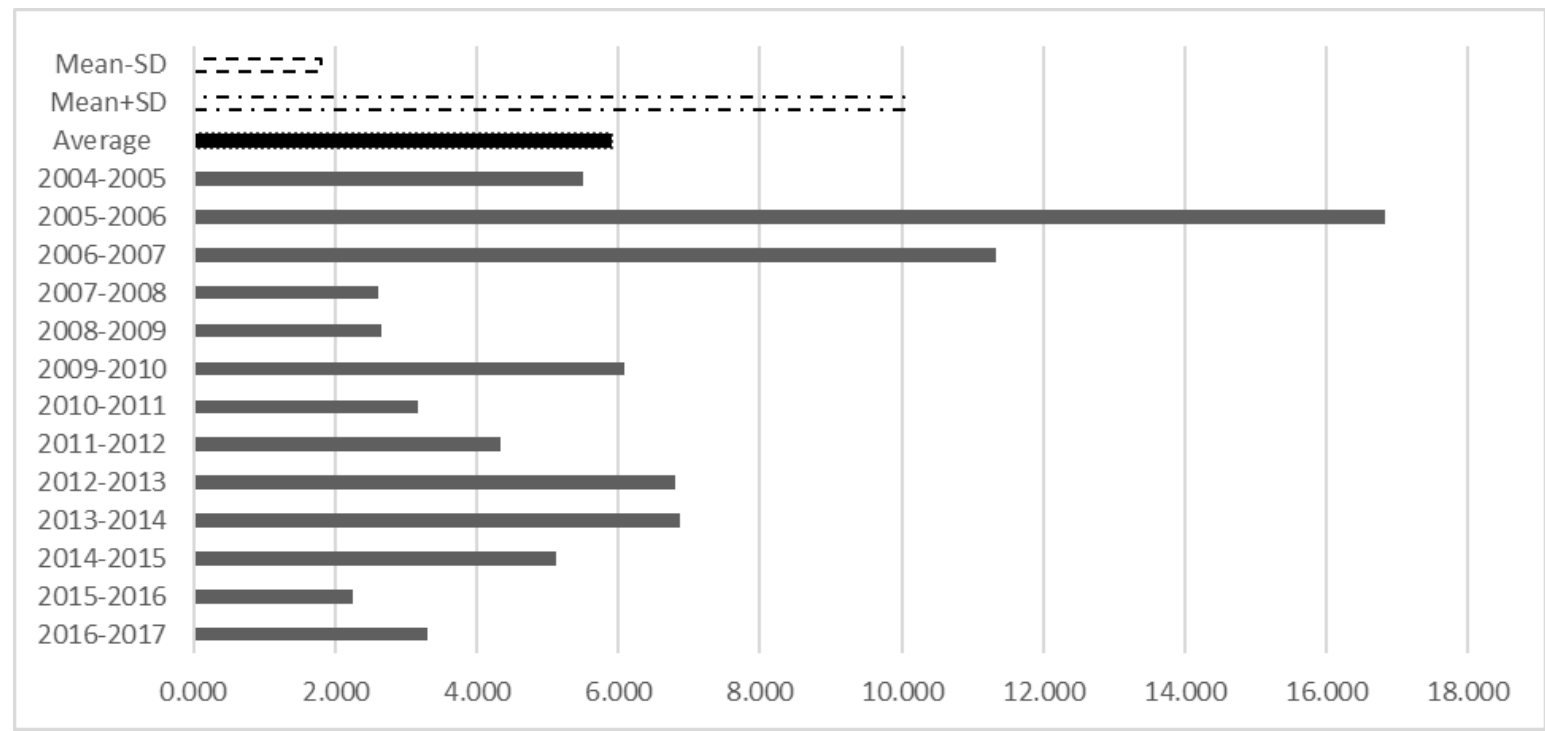

Figure 1. Descriptive statistics for Romania's UEFA country coefficients (2004-2017): Average (mean), Standard Deviation plus Mean, Standard Deviation minus Mean

Source: Author's own representation based on calculations of raw data retrieved from Kassies (2017).

First of all, the graphic shows that, for Romanian clubs to be considered as providing normal football in Europe, the country coefficient should have a value of 10.000 (to be correct, 10.020) each year. Only when being able to provide consecutive years with a country coefficient of 10.000 can local clubs claim that they have managed decent performances in European competitions. This has only happened twice, with the superior quality performances in 2005/2006 and in 2006/2007. Apart from these exceptions, Romanian club football cannot even claim it is anywhere near to decent performances, the closest coefficients to 10.020 being 6.083 (in 2009/2010), $6.800(2012 / 2013)$ and 6.875 (2013/2014 - a coefficient which is still 3.145 points below 'normal'). As a matter of fact, theses have also been the only three seasons above average (ordinary) results, while for 2016/2017, the coefficient has even been as low as 3.300. The rest of the seasons were not only below what statistics deem as 'normal', but also below the mean. Table 2 categorizes all seasons between 2004 and 2017 into five groups selected based on the mean and standard deviation calculations.

Table 2. Categorization of Romanian club football European seasons

\begin{tabular}{|l|c|c|}
\hline \multicolumn{1}{|c|}{ Rating } & $\begin{array}{c}\text { Nr. } \\
\text { seasons }\end{array}$ & Season \\
\hline $\begin{array}{l}\text { Superior quality } \\
\text { (above what is being perceived as normal; above 10.020) }\end{array}$ & 2 & $2005-2006,2006-2007$ \\
\hline Normal (at 10.020) & 0 & - \\
\hline Average (between the mean and normal) & 3 & $2009-2010,2012-2013,2013-2014$ \\
\hline $\begin{array}{l}\text { Below average } \\
\text { (between what is deemed as poor and average) }\end{array}$ & 8 & $\begin{array}{r}2004-2005,2007-2008,2008-2009, \\
2010-2011,2011-2012,2014-2015, \\
2015-2016,2016-2017\end{array}$ \\
\hline
\end{tabular}

Vol. 12, No. 4, Winter, pp. 652-673, ISSN 1842-0206| Management\& Marketing. Challenges for the Knowledge Society 
Very Poor

Source: Author's own conclusions based on computations of raw data retrieved from Kassies (2017).

Both Figure 1 and Table 2 show that the most European seasons of Romanian football have been below average (8), three were average and none really normal. Two of them were of superior quality, but this only comes as an exception, not as a status quo. Matters get even worse if we take into account the 95\% Confidence Level, which raises the lower value at 3.43, as can be seen in Figure 2 .

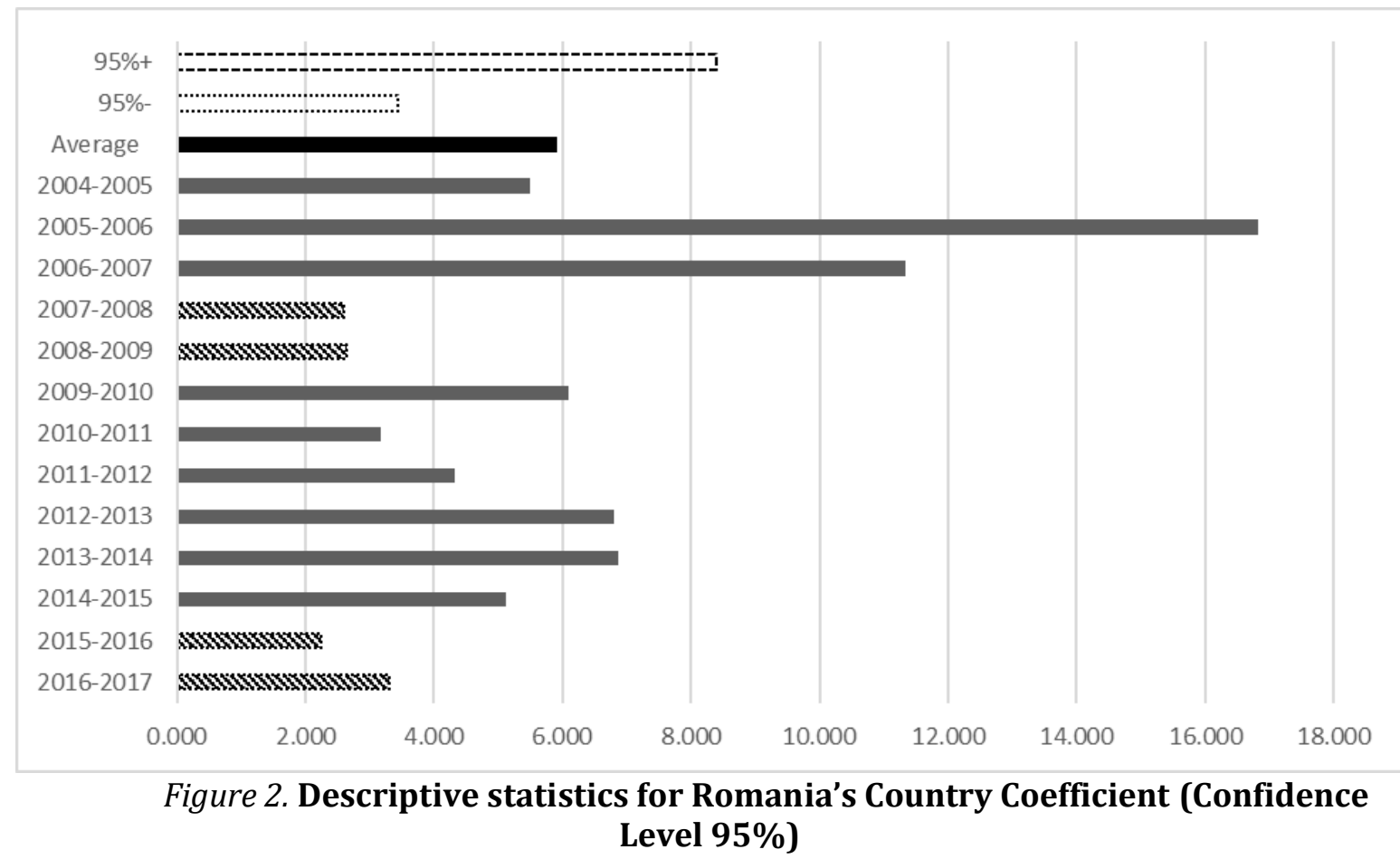

Source: Author's own conclusions based on computations of raw data retrieved from Kassies (2017).

If, at the top, the situation remains very much the same (with a value of 8.39 for the upper confidence interval, and only two seasons above the mean), the bottom of the table now shows that there are five seasons in which Romanian club football has underperformed (lines with patterns in the previous figure). The $95.0 \%$ Confidence Level claims that the true mean at which Romanian football clubs performed in Europe was situated somewhere between 3.43 points gathered per season and 8.39 points per season. However, there were five seasons in which Romanian clubs did not even manage to accumulate the minimum possible interval of points of 3.43.

Research results indicate that most of the performances of Romanian teams in European club competitions have been below average. The performances are characterized by strong fluctuations. This fact is indicated by the high range between the minimum and the maximum UEFA country coefficient values Romania had between 2004 and 2017: 14.583. For brief spells of time, Romania gave the impression that it could mingle with the continental elite, but it was later proved that the 2005-2007 and 2012-2014 intervals were only exceptions: domestic clubs have been unable to consolidate their position within the top, so were soon forced to return to performances below average. This demonstrates an inability to master control the

Vol. 12, No. 4, Winter, pp. 652-673, ISSN 1842-0206| Management\& Marketing. Challenges for the Knowledge Society 
process of Europeanisation. Being a non-uniform process in politics and football alike, one of the challenges of Europeanisation is the step-by-step growth until results polarize into a firm position. This is the case of Spanish and English football, which have been leading the UEFA country rankings for several years now, with fairly levelled coefficients (Spain between 20.000 and 24.000, England between 13.500 and 17.000). If Western European football is often regarded as a case apart, coming closer to Eastern European relationships, Russia's latest growth is to be taken into consideration, with coefficients constantly situated between 9.200 and 10.500 during 2013-2017. Romanian football has never had a spell of more than two years with coefficients over 9.000. Moreover, the long-term range fluctuations of the aforementioned countries are between 1.300 and 4.000, suggesting similar performances year over. In contradiction, Romania has struggled to keep a standard of results from year to year. Another impact on the coefficients comes from Romania's inability to provide a constant number of qualified teams, as opposed to fellow Balkan countries such as Greece or Turkey.

Figure 3 shows the fluctuations between better and worse results of Romanian club football in Europe. The punctuated line is the trendline of Romania's country coefficient and it reveals declining club performances on the long term. Evidence from this figure and the other ideas presented previously demonstrate that Romania cannot yet be considered a Europeanised country in terms of club football. Although it came close to the top in rare occasions, it couldn't maintain its position there.

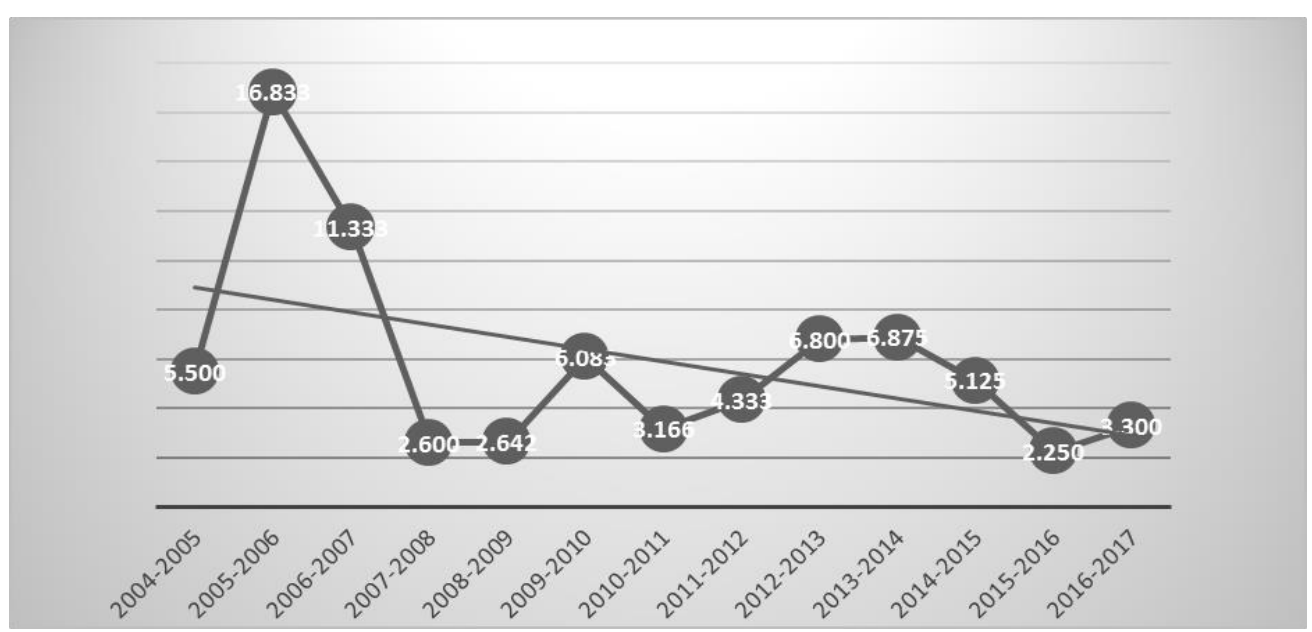

Figure 3. Evolution and trendline of Romania's UEFA Country Coefficient (2004-2017)

Source: Author's own representation based on raw data retrieved from Kassies (2017).

Figure 4 graphically displays the evolution of Romania's position in the UEFA country ranking coefficient since 1984 onwards (the vertical axis shows the position in the rankings and the horizontal axis displays the seasons). Ups and downs can be identified, with good performances being followed by abrupt falls, an inability to stay consistent. 


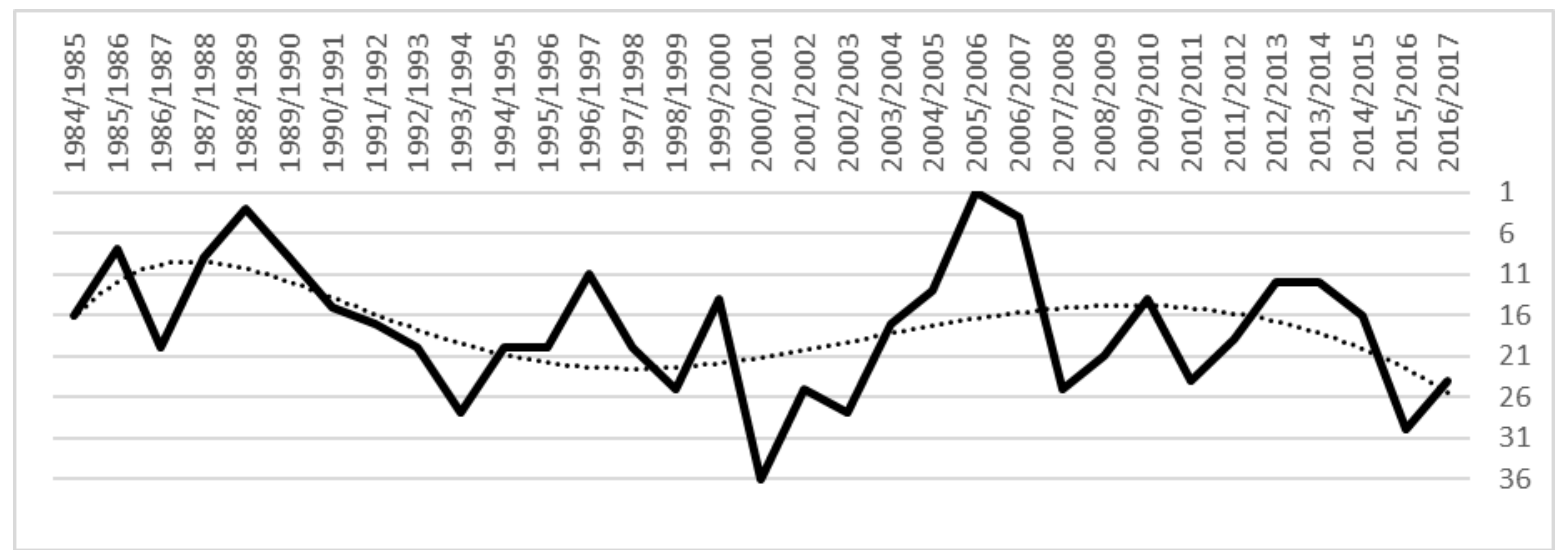

Figure 4. Romania's positions in the UEFA country rankings since 1984

Source: Author's own representation based on raw data retrieved from Kassies (2017).

\section{Results discussion}

Europeanisation as a scientific topic of interest has started receiving attention in the aftermaths of the Second World War in the Atlantic part of the continent (Anastasakis, 2005 , p. 78). What was coined as "Western style" Europeanisation was followed, decades later, by an "Eastern style" influenced by the fall of the Communist Bloc (Goetz, 2000). In this new optic, Europeanisation was meant to break the legacy of domestic administration into a developed, European way of doing things (Goetz, 2001, p. 1037). The reformative power was hoped to be seen not only in politics, but also in society and culture. Football joined the process of Europeanisation as one of those soft topics that Pyta (2015) argued were needed for having a full picture of the trial of modernization. As a Balkan country member of the former Bloc, Romania was part of the quest and, to some extent, football took a lead over politics in what concerned the transition from domestic towards European, with football clubs qualifying for international competitions sooner than the country joining international political and economic organizations. The dynamic of football results coming faster and, often, maybe even better than political results, should not wonder, as it is in line with Borneman and Fowler's opinion that sport is a "quintessential European pursuit and [...] an archetypical example of Europeanization" (1997, p. 508). Due to the simplicity of the game, football can lead to a fast Europeanisation, Romania's coefficient results of 2005-2007 and 2012-2014 being but two examples to prove this. However, these were only fast, concise spells of Europeanisation. What neither Romanian football, nor politics managed to accomplish yet, though, was to consolidate their position in Europe. Disparate periods of two years with good performances followed by abrupt falls are not enough for the process of Europeanisation to kick off its alignment procedures towards Western civilizations. For this to happen, Eastern European football clubs should perform at the top levels of international competitions for at least a medium-term period of years, i.e. five.

Moreover, one of the characteristics of "Eastern style" Europeanisation is that it will not lead to a uniform model of alignment (Caroli et al., 2014; Dinu, 2014; Grabbe, 2001). Not only that there will be inconsistencies between states, but there is also a risk of not properly mastering Europeanisation within national boundaries. Romanian football has demonstrated to stay in line with these attributes. The 
fluctuations of the UEFA country coefficients show that the Europeanisation process is not at all straightforward and takes more than expected. After having peaked coefficients in 2006 and 2007, Romania later returned to sub-average performances, with brief interruptions during three seasons when continental performances were distributed closer to normal. This sudden drop proves a resistance to transformation specific to CEE countries (Nunberg, 1999). András and Havran (2014) have tested their research hypothesis that football in the CEE region is deemed to sporting and financial failure, with the results of domestic clubs far from Western European standards. Jano (2008) believes that, prior to becoming Europeanised, states such as Romania first need to be "de-Balkanized", hence to break Goetz's (2001) legacy of the former. Judging on a long term, results obtained by Romanian clubs in European football competitions weren't either efficient, nor just. Apart from the 2005-2007 'uefantastic' period, results were below average and have hindered Romania from transforming its status in the relationship with other European football countries from "underdog" to "elitist". The dimensions of Romania's football relationships in Europe still need to be resized, but, for this, the country first needs to get back on proper course. The European results in the last three years (2014-2017) were below the 2004-2017 average $(\mu)$. Romanian clubs have to find their way back to at least performing average football in Europe, then try to go beyond and break the 10.000 level of what can be considered normal and decent performances. Up to today, most of the Romanian club's results in European cups have been rather partial than fundamental, with teams more likely to be rapidly eliminated than to reach top seeds. Socio-political reckonings on European integration deal with the idea of modernization. The sensible emphasis here is occupied by the urge made to postcommunist CEE countries to use the transition process for bridging the gap to the 'center' of the continent and move away from their 'peripheric' status.

König (1992) regards "the West" as the target to follow, so aligning results with Western European football can be considered as a constitutive portion in the modernization of domestic football. A first step towards the process of European modernization would be to lower the risk of being prematurely eliminated from the competition in the qualifying rounds. Seen as a catalyst for reform in post-communist Central and Eastern European countries or as an approximation to western continental standards (Featherstone, 1998), Europeanisation is still tabu for Romanian football, which is unable to send a consistent number of teams in UEFA competitions' round proper, let alone to perform at high standards. Habermas (1990) was talking about a post-communist 'catching up' with the West. Romanian football seems to have been played it over the past couple of decades, albeit never really with sound outcomes. The 'pluralization' that Habermas was urging is still belated by domestic underachievements in terms of football quality and management style. In football, Habermas' pluralization would mean to create a game that consists of more than one kind of class. European quality would be needed in addition to the domestic football. Unfortunately, the transfer between the two seems slow. Cox et all. (2017) ascribe this lentor to the pressures posed by the need to line up for an additional tournament, which, as demonstrated by Zambom-Ferraresi et all. (2017), brings along a waste of additional resources. However, Greece, Turkey or Russia avoided to be impacted to the same extent, and were earlier in this article provided as examples of

Vol. 12, No. 4, Winter, pp. 652-673, ISSN 1842-0206| Management\& Marketing. Challenges for the Knowledge Society 
countries that have managed to accomplish football pluralization, currently being able to send teams to the Champions League and to the Europa League year after year. Romania's chances to change its European dimension to the good can only increase once the country will become a constant presence in the Champions League, a competition that was last played by Steaua in 2013. For the moment being, the semiperipheric state of Romanian football sees a handful of the country's clubs struggling to produce results in the Europa League, with the elitist Champions League miles away. Football is relegated to a status of singularity with the domestic league, whereby it would be highly imperative to add a constant European dimension to this, so as to pluralize the soccerspace.

However, currently, not yet fully Europeanised, Romania is a semi-peripheral football country. Top 10 positions and coefficients over 10.000 were only obtained twice after 1989. In the rest of the years, Romania has occupied positions between $11^{\text {th }}$ and $36^{\text {th }}$, with results very often (eight times since 2004) below the average performances that clubs managed to obtain.

Romania's inability to become truly Europeanised can only be partially explained by several factors, a couple of which to be briefly illustrated here. First of all, probably the biggest problem in keeping Romanian football away from accelerating its Europeanisation process is what Meyer-Sahling (2001) and Zubek (2001) have termed as overarching influences of domestic actors, and Goetz (2001, p. 1039) as the contrast between hopes and results. In declarative terms, Romanian football club owners, directors, coaches, players and fans alike aspire to reach European heights. In spite of a 'catching up' discourse, the mindset of Romanian football is not fully transformed by Western societal norms, allowing opprobrium and mismanagement surrounding the domestic league to still shape the game's realities. This kind of behavior was termed by Tanasoiu (2012) as reassertive domestic structures, according to which the benefits of belonging to Europe are being delayed by the inability of domestic elites to internationalize their mindsets and separate from former manners of acting. Still caught up in domestic tensions and scandals, Romanian football actors see themselves launch declarative wishes of Europeanisation that are not matched by results on the playing field. Many of the talk-abouts do not do anything else than to raise expectations to a level difficult to match by game performances. The renowned avowal "lăsați-ne să ne pregătim de Champions League" („let us get ready for playing Champions League football”) periodically repeated almost to obsession by the owner of a club that has never got to play Champions League proper rounds epitomizes this contradiction between words and facts. Until yet, local football has been unable to completely transfer playing and administrative know-how gained through European participations over to the domestic league in order to reform and to enforce it, but it has mostly been the other way around, with ruinous domestic realities influencing the game and keeping it away from losing its semiperipherical status.

The center-periphery cleavage and UEFA's strategy to maximize the commercialism of the game can serve for explaining the second factor. Research indicates a high condensation of a few constantly participating teams in Europe, which Romania is not part of (Andreff, 2012, p. 91). Since 1998, Barcelona and Real Madrid have regularly played Champions League football, Bayern Munich and Manchester 
United have only missed one season each, while Arsenal London and Juventus Turin three, respectively four seasons. Since the same year 1998, Steaua Bucuresti, the most successful Romanian club in the competition, has only entered the Champions League four times, and CFR Cluj on three other occasions. Since 1992, Spain has had 83 participations in the Champions League (total number of clubs qualified each year), England 80, Germany 70, Italy 70, France 58, Portugal 47, the Netherlands 37, Russia 35, Greece 31, while Romania only 12 (Steaua 7, CFR Cluj 3, Unirea Urziceni 1, Otelul Galati 1). Andreff has calculated that roughly $80 \%$ of participating clubs are the same year over, transforming the Champions League into a tournament circumscribed to the rich elites of football. Considering that the total money prizes for the 2016-2017 were in the height of 2.3 billion euros, with each of the tournament's finalists cashing in about 100 million euros, while only the mere participation in the competition without even winning one match guaranteed 12.5 million euros (with prizes increasing based on performances), it can be argued that a) not qualifying for the European competitions keeps Romanian clubs away from additional considerable financial revenue and also widens the gap to the elites of continental football as b) the powerhouses of Europe constantly qualify for continental competitions and win prizes that make the rich become even richer, while poorer clubs stand watching by. The competitive balance inclines towards the rich clubs, which, constantly winning more, have sounder financial accounts that allow them to pay better wages and bonuses, to recruit better, ultimately to distance themselves from the other teams (read nonEuropean-participating) in their national competitions, and almost safeguarding their presence in the forthcoming season of continental football based on the increasing distances towards the "poorer" teams. Andreff and Szymanski (2006) put this as the contradiction between the "vicious" and the "virtuous" circles: while the "poor" clubs are grounded in the vicious circle of non-participation (loss of money, prestige and bargaining power), the "rich" clubs enter the virtuous circle of participation (win of money, prestige and bargaining power), which leads to revenue disparities, leaving second or third world footballing nations such as Romania even further behind (Vrooman, 2007).

\section{Conclusions and future research}

Research results confirm the research hypothesis that Romania has a peripheral dimension in European football, yet it has to be mentioned that some middle ground needs to be found. Although definitely not at the top, Romanian football isn't either at the lowest level possible, but in between the two: whilst domestic football clubs have enjoyed several satisfactory seasons in European competitions, these were not the norm, but only exceptions, leaving the country to struggle somewhere between good and poor. The concept of the paper was created on Brand and Niemann's (2007) idea that stepping up to a glorious European dimension can help domestic clubs modernize their football by breaking loose from their murky domestic realities, hence to move from the periphery to an evolved center. Two pillars supporting these ideas are the extra, considerable financial revenues and the playing know-how that can be gained by participating in football. The shift from a meager periphery to a posh center is especially needed for CEE countries members of the former Communist Bloc (Gorzelak et all., 2013). As observed by Racoviţă (2011) and by Papadimitriou and 
Phinnemore (2004), though, the Europeanisation process of Romania is slow, be it in politics or football. European football still looks like an asymmetric game of multiple magnitudes, the Eastern delayed from the West in terms of playing quality and money involved (Brand and Niemann, 2013; Schwell, 2015; Spaaij, 2006). In order to align with Western European soccer practices, Romanian football clubs need to perform well in Europe. Nonetheless, the analysis of the UEFA Country Coefficients has shown that most of Romania's European seasons have been average or below average.

This article can contribute to knowledge advancement by answering the need for different scientific models of Europeanisation, not limited to the hardcore topics of finance or politics. It does so by having a look at the post-communist European dimension of Romanian football. This soft-side, social orientation can serve both fans and decision-makers alike. For fans, the results of this paper can help in re-sizing expectations. Fans usually have got high expectations from their teams, looking for them to perform well. As shown by this paper, having high expectations might add extra pressure to coaches and footballers, as the reality indicates that on-pitch results are lower than what is expected. The same should be understood by club managers and officials, who should moisten their declarations concerning European glory. Steaua, Rapid and Dinamo have contributed to a great 2005/2006 "uefantastic" season, yet Romania was unable to maintain that status and has later returned to its semi-peripheric dimension. Fans and officials should understand that domestic soccer needs a thorough modernization process. The modernization would have to start with building the ability to constantly (year-over) qualify more teams to the rounds proper of European competitions, and then also improve results obtained there. For the moment being, research has indicated strong fluctuations in results, showing that Romanian club football is facing instability in Europe. Many of Romania's qualifications in post-round-robin phases between 2004 and 2017 have been obtained by Steaua Bucuresti, but it would be misleading to confuse one team with the entire country. Irrespective of Steaua's performances, most of the other clubs (probably apart from CFR Cluj) have struggled in Europe. If aiming to become a force in Europe, Romania has to understand that it needs to do so with more than one or two clubs. Spain's and England's dominant positions have been obtained because these countries constantly play in Europe with seven clubs yearly, four or five of them in the Champions League. For the moment, Romania is still far away from this situation. So as the evolution curve looks like, there is a menace for Romania to be relegated from a semi-peripheral to a truly peripheral position in European football rather than to climb to the center of it. Immediate action and a change of mindset towards alignment with Western European practices are needed to avoid this and for overall competitivity (Hadad and Gauca, 2014). Football clubs need to build a competitive edge for creating stronger relationships with their fans and stakeholders (Ercsey, 2017; Tóth Attila, 2016; Wroblowská, 2016).

For people directly involved in Romanian football, this paper can serve as a synthesis of how domestic clubs have performed at an international level. Apart from this minority group, the paper could be relevant to readers interested in European integration, not necessarily in sports. In this case, football is just a vehicle to show that the process of Europeanization can occur in different areas, not only in politics and economics. This paper tries to make a point for 'non-technical' readers (i.e. not 
interested in football) that a nation can trully call itself Europeanized only when different dimensions of its civic space (culture, sports, public administration etc.) are being aligned with European values. Being a game easy to understand worldwide, with a simple 'language', football is one of the best ambassadors that can help in improving the PR of a country. In the particular case of this reseach, football can also be one of the vectors that a country could use to make a statement about its European dimension.

One of the major limitations of the research is that it only considers Europeanization from a results-oriented point of view. What a true "European" level of football really means cannot only be based on results produced in continental competitions. Being Europeanized means more than obtaining good results in international tournaments. It is also a matter of the well-functioning of sporting institutions, of having order and harmony in the sports sector, as well as employing the most competent people not only on the playing field, but also in sportsadministrative functions. Future research should further investigate the European dimension of Romanian football by also making a structural analysis of the organization and management of the game. Another limitation is that this research has chosen not to make a comparison with the coefficients of other UEFA member associations, but to only look at Romania's own country coefficients and learn from what they can show. This choice was motivated by the idea that, prior to international comparative studies, it is important to understand how Romania's own performances have changed historically over years. The method has helped in understanding internal realities, although a second criticism that can be brought to it is that it has only taken into consideration a span of thirteen years (starting with 2004 up to date), ignoring what has happened until 2004, especially after the Revolution of 1989 (which has started the transition process of Romanian society) and after the changes made by UEFA starting with 1992 (that have re-defined the European competitional aspect). Even though, throughout its lines, the research touches points with these two historical dates to help explain its findings, it has omitted them from the data sampling. As UEFA competition formats were modified a lot during the last 25 years, going too much behind would have probably distorted the results. 2004 has been chosen as a starting year as it offered enough depth for relevant results (and avoided different formulas of UEFA index calculations, argument justified in the Methodology section), although alternative research might also investigate data from the early 1990's. In a similar fashion, this research can be a starting point for a future comparative study that would need to look at how Romania performed against its continental counterparts by comparing coefficients of different UEFA member countries among them. Such a study would add necessary parts to a gap left open by this research.

\section{References}

Afonso, A. (2010), "Policy concertation, Europeanization and new political cleavages: The case of Switzerland", European Journal of Industrial Relations, Vol. 16, No. 1 , pp. 57-72.

Anastasakis, 0. (2005), “The Europeanization of the Balkans”, The Brown Journal of World Affairs, Vol. 12, No. 1, pp. 77-88. 
András, K. and Havran, Z. (2014), "Regional Export Efficiency in the Market of Football Players", Theory Methodology Practice, Vol. 10, No. 2, pp. 3-15.

Andreff, W. (2012), "Sport events, economic impact and regulation", in: Desbordes, M. and Richelieu, A. (eds.), Global Sport Marketing: Contemporary Issues and Practice, pp. 83-109, Routledge, London/New York.

Andreff, W. and Szymanski, S. (2009), Handbook on the Economics of Sport, Edward Elgar Publishing, Cheltenham/Northampton.

Atikcan, E.O. (2010), "European Union and Minorities: Different Paths of Europeanization?", Journal of European Integration, Vol. 32, No. 4, pp. 375-392.

Borneman, J. and Fowler, N. (1997), "Europeanization", Annual Review of Anthropology, Vol. 26, pp. 487-514.

Börner,S. and Eigmüller, M. (2015), European Integration, Processes of Change and the National Experience, Springer Verlag, Berlin.

Brand, A. and Niemann, A. (2006), "The Europeanization of German Football", in: Tomlinson, A. and Young, C. (eds.), German Football: History, Culture, Society, pp. 127-142, Routledge, London/New York.

Brand, A. and Niemann, A. (2007), "Europeanisation in the societal/trans-national realm: What European Integration Studies can get out of analysing football", in: Conference of the European Union Studies Association (EUSA), Montréal, May 2007, available at: http://aei.pitt.edu/7712/, (accessed September 24, 2017).

Brand, A., Niemann, A. and Spitaler, G. (2013), „The two-track Europeanization of football: EU-level pressures, transnational dynamics and their repercussions within different national contexts", International Journal of Sport Policy and Politics, Vol. 5, No. 1, pp. 95-112.

Buller, J. and Gamble, A. (2002), “Conceptualising Europeanisation”, Public Policy and Administration, Vol. 17, No. 2, pp. 4-24.

Bürzel, T. A. (1999), "Towards convergence in Europe? Institutional adaptation to Europeanization in Germany and Spain", Journal of Common Market Studies, Vol. 37, No. 4, pp. 573-596.

Carbone, M. and Quartapelle, L. (2016), "Italy's development policy and the domestic politics of Europeanisation: why Europe matters so little", European Politics and Society, Vol. 17, No. 1, pp. 42-57.

Caroli, L., Genga, N., Imbernon, A. and Stănescu, I. (2014), "Towards A New European Polity? Social Democrats and the 2014 EP Elections", Journal of Community Positive Practices, Vol. 14, No. 2, pp. 81-114.

Champion, T.C. (2005), Centre and Periphery: Comparative Studies in Archaeology, Routledge, London/New York.

Collie, A.J. (2003), World of Soccer: A Complete Guide to the World's Most Popular Sport, The Rosen Publishing Group, Inc., New York.

Cowles, M. G., Caporaso, J. A. and Risse-Kappen, T. (2001), Transforming Europe: Europeanization and domestic change, Cornell University Press.

Cox, A., Gilmore, S. and Graham, A. (2017), "The European dilemma: evaluating the implications of UEFA Europa League participation on English Premier League clubs", Soccer \& Society, Vol. 18, No. 7, pp. 817-835. 
Denti, D. (2014), "The Europeanisation of candidate countries: the case for a shift to the concept of EU member-state building", Contemporary Southeastern Europe, Vol. 1, No. 1, pp. 9-32.

Dinu, A. (2014), "From European Migrants to European Citizens: An Unfinished Process", Journal of Community Positive Practices, Vol. 14, No. 1, pp. 15-26.

Dunmore, T. (2011), Historical Dictionary of Soccer, The Scarecrow Press, Inc., Lanham/Toronto/Plymouth.

Economides, S. (2005), “The Europeanisation of Greek Foreign Policy”, West European Politics, Vol. 28, No. 2, pp. 471-491.

Ercsey, I. (2017), “The role of customers' involvement in value co-creation behavior: Is value co-creation the source of competitive advantage?", Journal of Competitiveness, Vol. 9, No. 3, pp. 51-66.

Featherstone, K. (1998), “'Europeanization' and the centre periphery: The case of Greece in the 1990s", South European Society and Politics, Vol. 3, No. 1, pp. 2339.

Flores, R., Forrest, D., de Pablo, C. and Tena, J.D. (2015), "What is a good result in the first leg of a two-legged football match?", European Journal of Operational Research, Vol. 247, No. 2, pp. 641-647.

Geeraert, A. (2016), The EU in International Sports Governance: A Principal-Agent Perspective on EU Control of FIFA and UEFA, Palgrave Macmillan, Basingstoke.

Gherghina, S. (2013), "Ethnic citizenship regimes: europeanization, post-war migration and redressing past wrongs", Journal of Ethnic and Migration Studies, Vol. 39, No. 6, pp. 1038-1039.

Goetz, K. H. and Hix, S. (2001), Europeanised politics? European integration and national political systems, Frank Cass Publishers, Oxon.

Goetz, K.H. (2000), "European integration and national executives: A cause in search of an effect?", West European Politics, Vol. 23, No. 4, pp. 211-231.

Goetz, K.H. (2001), "Making sense of post-communist central administration: modernization, Europeanization or Latinization?", Journal of European Public Policy, Vol. 8, No. 6, pp. 1032-1051.

Gorzelak, G., Maier, G., and Petrakos, G. (2013), Integration and transition in Europe: the economic geography of interaction, Routledge, London/New York.

Grabbe, H. (2001), "How does Europeanization affect CEE governance? Conditionality, diffusion and diversity", Journal of European Public Policy, Vol. 8, No. 6, pp. 1013-1031.

Habermas, J. (1990), Die nachholende Revolution, Suhrkamp, Frankfurt am Main.

Hadad, S. and Găuca, O.D. (2014), "Social impact measurement in social entrepreneurial organizations", Management \& Marketing. Challenges for the Knowledge Society, Vol. 9, No. 2, pp. 119-136.

Haughton, T. (2007), "When does the EU make a difference? conditionality and the accession process in Central and Eastern Europe”, Political Studies Review, Vol. 5, No. 2, pp. 233-246.

Holt, M. (2007), "The ownership and control of elite club competition in European football", Soccer \& Society, Vol. 8, No. 1, pp. 50-67.

Hrebenciuc, A. (2017a), "Banking union framework and the stability of the European banking sector", Theoretical and Applied Economics, Vol. 24, No. 1, pp. 291-298. 
Hrebenciuc, A. (2017b), "The costs of Brexit for UK economy", Theoretical and Applied Economics, Vol. 24, No. 2, pp. 319-327.

Hughson, J., Moore, K., Spaaij, R. and Maguire, J. (2016), Routledge Handbook of Football Studies, Routledge, London/New York.

Ilieva, P. and Wilson, T.M. (2011), "Euroscepticism and Europeanisation at a margin of Europe", Anthropological Journal of European Cultures, Vol. 20, No. 2, pp. 87113.

Jano, D. (2008), “From 'Balkanization' to 'Europeanization': The stages of Western Balkans complex transformations", L'Europe en formation, Vol. 3, pp. 55-69.

Kassies, B. (2017), "UEFA European Cup Football. Results and Qualification", available at: https://kassiesa.home.xs4all.nl/bert/uefa/ (accessed September 11, 2017).

Kassimeris, C. (2007), European Football in Black and White: Tackling Racism in Football, Lexington Books, Lanham/Boulder/Plymouth.

Kayna, V., Karolewski, I.P. and Kuhn, S. (2015), European identity revisited: New approaches and recent empirical evidence, Routledge, London/New York.

Kesenne, S. (2007), "The peculiar international economics of professional football in Europe", Scottish Journal of Political Economy, Vol. 54, No. 3, pp. 388-399.

Ladrech, R. (1994), "Europeanization of domestic politics and institutions: The case of France", Journal of Common Market Studies, Vol. 32, No. 1, pp. 69-88.

Lago, I., Lago-Peñas, C. and Lago-Peñas, S. (2016), "Democracy and football", Social Science Quarterly, Vol. 97, No. 5, pp. 1282-1294.

Lippert, B., Umbach, G. and Wessels, W. (2001), "Europeanization of CEE executives: EU membership negotiations as a shaping power", Journal of European Public Policy, Vol. 8. No. 6, pp. 980-1012.

Lodge, M. (2002), "Varieties of Europeanisation and the national regulatory state", Public Policy and Administration, Vol. 17, No. 2, pp. 43-67.

Martin, P. (2005), “The 'Europeanization' Of Elite Football”, European Societies, Vol. 7, No. 2, pp. 349-368.

McNamara, K.R. (2015), The Politics of Everyday Europe: Constructing Authority in the European Union, Oxford University Press, Oxford/New York.

Menary, S. (2016), "One rule for one: the impact of Champions League prize money and Financial Fair Play at the bottom of the European club game", Soccer \& Society, Vol. 17, No. 5, pp. 666-679.

Meyer-Sahling, J.H. (2001), "Getting on track: civil service reform in post-communist Hungary", Journal of European Public Policy, Vol. 8, No. 6, pp. 960-979.

Morgan, J. (2017), For the Love of Football: A Companion, Summersdale Publishers, Chichester.

Morrow, S. (2003), The People's Game?: Football, Finance and Society, Palgrave Macmillan, Basingstoke/New York.

Mutz, M. (2015), "Transnational Public Attention in European Club Football: Current trends and driving forces", European Societies, Vol. 17, No. 5, pp. 724-746.

Niemann, A., Garcia, B. amd Grant, W. (2011), "Introduction: the transformation of European football", in: Niemann, A., Garcia, B. and Grant, W. (eds.) The transformation of European football: Towards the Europeanisation of the national game, pp. 1-22, Manchester University Press, Manchester/New York. 
Olsen, J. P. (2002), "The many faces of Europeanization", Journal of Common Market Studies, Vol. 40, No. 5, pp. 921-952.

Olsson, L.C. (2011), "Decisive Moments in UEFA", in: Gammelsæter, H. and Senaux, B. (eds.) The Organisation and Governance of Top Football Across Europe: An Institutional Perspective, pp. 17-31, Routledge, New York/London.

Özer, Y. (2016), Turkey and the European Union: Processes of Europeanisation, Routledge: London/New York.

Page, L. and Page, K. (2008), “The Second Leg Home Advantage: Evidence From European Football Cup Competitions", in: Andersson, P., Ayton, P. and Carsten Schmidt (eds.) Myths and Facts about Football: The Economics and Psychology of the World's Greatest Sport, pp. 131-148, Cambridge Scholars Publishing, Newcastle Upon Tyne.

Papadimitriou, D. and Phinnemore, D. (2004), "Europeanization, conditionality and domestic change: The twinning exercise and administrative reform in Romania", Journal of Common Market Studies, Vol. 42, No. 3, pp. 619-639.

Pavlovaite, I. (2003), "Being European by Joining Europe: Accession and identity politics in Lithuania", Cambridge Review of International Affairs, Vol. 16, No. 2, pp. 239-255.

Pisciotta, B. (2016), "The Center-Periphery Cleavage Revisited: East and Central Europe from Postcommunism to Euroscepticism", Nationalism and Ethnic Politics, Vol. 22, No. 2, pp. 193-219.

Postiglione, G.A. (2005), "Questioning Centre-Periphery Platforms", Asia Pacific Journal of Education, Vol. 25, No. 2, pp. 209-225.

Pyta, W. (2015), "Introduction: Football Memory in a European Perspective”, in: Pyta, W. and Havemann, N. (eds.) European Football and Collective Memory, pp. 1-17, Palgrave Macmillan, Basingstoke/New York.

Racoviţă, M. (2011), "Europeanization and Effective Democracy in Romania and Bulgaria", Romanian Journal of Political Sciences, Vol. 11, No. 1, pp. 28-49.

Rees, N. and Connaughton, B. (2009), "Europeanisation: a catalyst for change", in: Rees, N., Quinn, B. and Connaughton, B. (eds.) Europeanisation and new patterns of governance in Ireland, pp. 12-33, Manchester University Press, Manchester/New York.

Rodríguez, P., Késenne, S. and Koning, R. (2015), The Economics of Competitive Sports, Edward Elgar Publishing, Cheltenham/Northampton.

Schulz, M.A. (2008), Alles über Fußball, Wissen Media Verlag, Gütersloh/München.

Schwell, A. (2015), "Offside. Or Not Quite. Euro 2012 as a Focal Point of Identity and Alterity", in: Sonntag, A., Schwell, A. and Alpan, B. (eds.) The European Football Championship: Mega-Event and Vanity Fair, pp. 22-53, Palgrave, Basingstoke.

Sofos, S.A. (2009), "Reluctant Europeans? European Integration and the Transformation of Turkish Politics", South European Society and Politics, Vol. 5, No. 2, pp. 243-260.

Spaaij, R. (2006), Understanding Football Hooliganism: A Comparison of Six Western European Football Clubs, Amsterdam University Press: Amsterdam.

Szerovay, M., Itkonen, H. and Vehmans, H. (2017), “'Glocal' processes in peripheral football countries: a figurational sociological comparison of Finland and Hungary", Soccer \& Society, Vol. 18, No. 4, pp. 497-515. 
Tanasoiu, C. (2012), "Europeanization post-accession: rule adoption and national political elites in Romania and Bulgaria", Southeast European and Black Sea Studies, Vol. 12, No. 1, pp. 173-193.

Tóth Attila, A. (2016), "The Impact of the Hotel Industry on the Competitiveness of Tourism Destinations in Hungary", Journal of Competitiveness, Vol. 8, No. 4, pp. 85-104.

Vrooman, J. (2007), "Theory of the beautiful game: The unification of European football", Scottish Journal of Political Economy, Vol. 54, No. 3, pp. 314-354.

Wessels, W. (2000), Die Öffnung des Staates: Modelle und Wirklichkeit grenzüberschreitender Verwaltungspraxis 1960-1995, Leske \& Budrich, Opladen.

Wroblowská, Z. (2016), „Requirements for Brand Managers and Product Managers Responsible for Competitiveness of Product and Brands", Journal of Competitiveness, Vol. 8, No. 3, pp. 5-21.

Yllmaz, G. (2016), "Europeanisation or De-Europeanisation? Media Freedom in Turkey (1999-2015)", South European Society and Politics, Vol. 21, No. 1, pp. 147-161.

Zambom-Ferraresi, F., García-Cebrián, L.I., Lera-López, F. and Iráizoz, B. (2017), "Performance evaluation in the UEFA Champions League", Journal of Sports Economics, Vol. 18, No. 5, pp. 448-470.

Zgaga, P. (2014), "The role of higher education centres in research and policy: a case from a European periphery", Studies in Higher Education, Vol. 39, No. 8, pp. 1393-1404.

Zubek, R. (2001), "A core in check: the transformation of the Polish core executive", Journal of European Public Policy, Vol. 8, No. 6, pp. 911-932. 